\title{
Livelihoods Means and Local Populations Strategies of the Luki's Biosphere Reserve in Democratic Republic of Congo
}

\author{
Jean Semeki Ngabinzeke ${ }^{1,}$, , Yves Meyanga Tongo ${ }^{2}$ \\ ${ }^{1}$ Naturel Resources Management Department, Faculty of Agricultural Sciences, University of Kinshasa, Kinshasa, Democratic Republic of \\ Congo (DRC) \\ ${ }^{2}$ Agro Economist and Tropical Forests and Land Management in the National Center of Education of the Ministry of Scientific Research and \\ Innovation Yaoundé, Yaoundé, Cameroon
}

\section{Email address:}

jeansemeki@gmail.com (J. S. Ngabinzeke), meyangayves@gmail.com (Y. M. Tongo)

${ }^{*}$ Corresponding author

\section{To cite this article:}

Jean Semeki Ngabinzeke, Yves Meyanga Tongo. Livelihoods Means and Local Populations Strategies of the Luki's Biosphere Reserve in Democratic Republic of Congo. International Journal of Natural Resource Ecology and Management. Vol. 4, No. 2, 2019 , pp. $42-49$.

doi: 10.11648/j.ijnrem.20190402.12

Received: March 15, 2019; Accepted: April 26, 2019; Published: May 17, 2019

\begin{abstract}
The Luki's Biosphere Reserve (LBR), latter remnant Mayombe's forest in Democratic Republic of Congo, is exposed to a prominent human pressure. After the independence process that occurred in the country, the "zaïrianization" policy of nationalization lead to the agro-industrial collapse. Face to that situational configuration and then compelled to unemployment, the population turned on forest activities, such as, slash and burn shifting cultivation, carbonization, operating timber and hunt, which tend to be their main basic live hoods means. The problem of this study is, based on how local populations tend to survive despite the crises and above any lack of support? Responding to that preoccupation, an investigation focus on systemic analyses of various ways of subsidence had been realized in four (04) local villages of the reserve: Kinzua-Mvuete, Kikalu, Kiyalala, Kiyangala. Data's collecting through a systemic approach and analysis shown a serious dependence toward forest resources; in a stamped context of demographical progression, generalized by poverty and weaknesses of environmental governance, the populations have developed several strategies of survive in terms of, intensification, diversification and migration. Those assorted activities consisted especially to the non-respect of the fallow period, the land dispute, the felling of small diameter trees, the modification of land use, conducting to deforestation and to degradation, increase therefore misery. In order to reconcile the objectives of development and conservation: agroforestry, fish farming, beekeeping, and sensitization have been suggested.
\end{abstract}

Keywords: Livelihoods Means, Strategies, Local Populations, Luki Biosphere Reserve, Anthropic Pressures, Environmental Governance

\section{Introduction}

The Democratic Republic of Congo (RDC) is composed of one hundred and forty-five million hectares in terms of forest resource. With deforestation rate is relatively equal to $0.25 \%$ and with a wasted forest material represented tree hundreds and eleven thousands hectares per year, the country is classified at the $7^{\text {th }}$ position in the world within others countries in terms of exhausted area forest cover [2, 18]. A pre-analyze identified four main factors of deforestation and forests destructions in DRC: agricultural activities and firewood recovery, forest trade exploitation, roads infrastructures and mining operation $[5,12,17]$. Face up to the climate change challenge's and confronted to the challenge of forest preservation, the country involved to the REDD++ strategical preparation processes and implicated to an operational strategical action since 2013. The REDD ++ strategy has two majors' objectives: reducing emissions occurred through deforestation and forest degradation; reducing poverty, according to DRC' poverty strategical document reduction $[3,4]$.

Actually, the data and experiences at the disposal of the country seem to be partial and insufficient to build it strategy. 
It will be therefore appropriate to exploit various REDD++ strategical options through field' investigation, in order to test the different conditions of implementation (legal, organizational, financial and human) [4].

The Kongo-Central region in DRC, singularly, across Luki' biosphere reserve (LBR), remains an adequate field of our study [1, 14]. That region in respect of it geographical convenience and forestry potential, attracted an important agro-forestry's colonial enterprises. Those enterprises have gratefully contributed to reinforce the socio-economic architecture of the region longtime ago. This past situational configuration has limited anthropic pressures on natural resources. The political processes of "zairainization" conducing to a general nationalization of privates' enterprises, many of national industries collapsed in the early years of 1990. Desperate and putting into poverty situation, populations organized their selves to survive, by their involvement of some forest activities, with high negative impacts in environment such as, slash and burn shifting cultivation, carbonization, operating timber and hunt $[1,15]$.

Therefore it's obvious that only the conciliation of socio economic development goals and natural resources protection issues will constitute the theoretical framework for sustainable actions. So, in order to bring up an appropriate solution to the above situation, it will be surely benefic to set of the problem through a holist epistemological approach. Subscribing to that theoretical perspective, this study proposed to analyze local population surviving strategies in order to proposed sustainable answers. Identify and analyze human, natural, physic, financial and social peasant' resources and livelihoods means, remain ours specifics objectives.

\section{Materials and methods}

\subsection{Study's Ground}

The present study has been realized at Kinzau Mvuete city, specifically at Kiyalala, Kikalu and Kiyangala villages, which belong to Kungu Yalala grouping neighboring zone, inside Nseke Banza region, precisely in the bas-fleuve district, and globally in Kongo-Central province.

Kinzua city is located at $05^{\circ} 29^{\prime} 48,6^{\prime \prime}$ of Southern latitude and at $013^{\circ} 17^{\prime} 21,4^{\prime \prime}$ of East longitude. Kiyala is located at $05^{\circ} 31^{\prime} 10,8^{\prime \prime}$ of southern latitude and at $013^{\circ} 16^{\prime} 59,0^{\prime \prime}$ East longitude, Kikalu at $05^{\circ} 31^{\prime} 36,9^{\prime \prime}$ of southern latitude and at $013^{\circ} 16^{\prime} 35,4^{\prime \prime}$ of East longitude and Kiyangala at $05^{\circ} 31^{\prime} 58,3^{\prime \prime}$ of southern latitude and at $013^{\circ} 16^{\prime} 26,8^{\prime \prime}$ of East longitude [1, $15]$.

The Kinzua Mvuete and the tree others studied villages relief is structured by hills, slopes and valleys. The climate situation is characterize by a tropical damp, determine by a dry season of four months going from the middle of May to the middle of September. Average temperature is situated around $25^{\circ} \mathrm{C}$. The annual average precipitations are $1120 \mathrm{~mm}$ $[6,14]$. The soils are sandy clay. The vegetation is specific to Mayombe forest: thick forest, semi-deciduous, grassy savannas, strub, and secondary forest $[1,14]$. This vegetation is demoted by human activities $[15,16]$.

\subsection{Data Set and Theoretical Process Analyzes}

The complexity, the variability, and the interactions of variables which characterized rural development broadly and specifically the landscape subsystems of the area of study, lead us to adopt a mix methodology approach which imply the use of quantitative and qualitative data's is responded to the principle of systematic approach which constitute the theoretical framework of this study.

A systemic approach is mobilized in the courant study as a theoretical process analyses, consist in the examination of different interactions between the sub-systems that composing the general system [1]. Four types of data's collecting instruments or tools have been put into contribution to carry out field information's of this study such as: direct observation, focus group, interview and questionnaire. A direct observation has been done throughout a transect which enable the possibility to catch up the social reality on the field (figure 1).

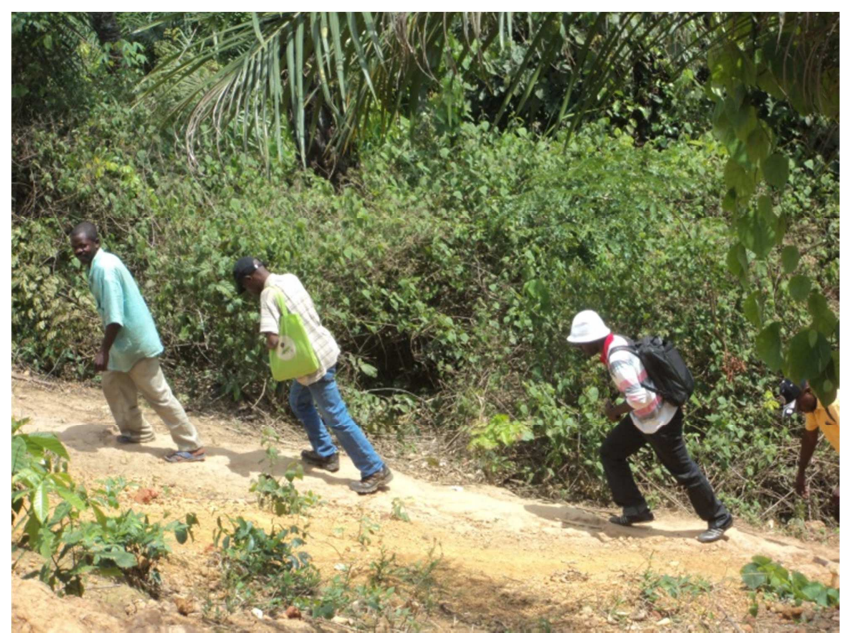

Figure 1. Transect walk to Kinzau Muete. P. Yves Meyanga.

Six focus groups were put in place within the local population (figure 2). Respondents were local population such as traditional and professional group leaders considered as primary respondents, the state structure civil servants and NGOs leaders involved in environmental domain and forest management constitute our secondary respondents. About 14 persons were interviewed, and a questionnaire has been administrated to 27 persons partaking into many surviving activities. It was necessary in an inclusive participatory approach before conducting an inquiry to require among respondents their free and conscious consent. This agreement was obtain trough several trainings and sensitization meetings with local stakeholders. In another hand, information's concerning the description of the context of study, for instance socio economy parameters was collected through literature review such as local archive service. 


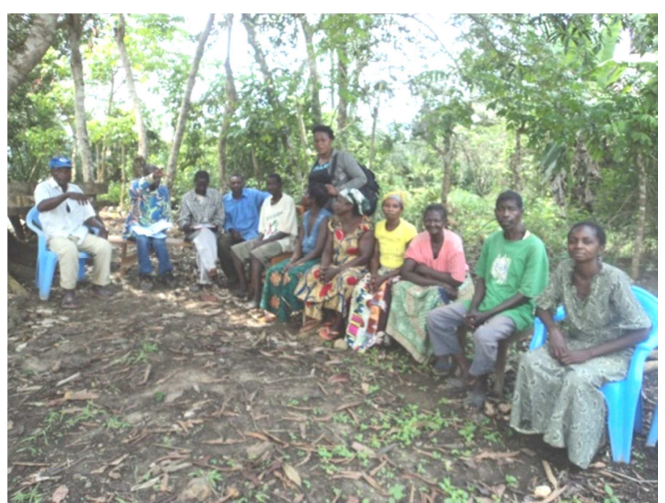

Figure 2. Focus groups to Kiyangala. P. Yves Meyanga.

Excel spreadsheet has been used to setup a synoptic data collected base. In terms of graphical production and data's boards setting. Some difficulties were observed on the matter concerning the providing of information by certain inquired populations.

\section{Results}

\subsection{Human Capital}

Human capital is meaning taking in consideration socio economy and human parameters to explain and analyses facts. In this case demographic indicators (age, social status, matrimonial status, level of formal education) and access to socioeconomic facilities (access to education and health) have been set up to tackle this issue.

The Kinzau Mvuete city ages configuration are presented throughout Figure 3. The enlarged base ages pyramid of Kinzau Mvuete city are constitutive of a high number of children, within zero and four years old, consubstantial to a prominent birth rate. $62.37 \%$ of the population is less than thirty years old. Men ages' intervals comprised within 20-24 years old, 25-29 years old and 30-34 years old remain insignificant, explaining the various men emigrations for better areas life's conditions such as Cabinda, Pointe Noire and Soyo. Jobs seekers and agricultural land accessibility contributed to the implantation of immigrant to Tshela, Lukula, Boma territories; Matadi and Kinshasa neighboring. The top of the pyramid shows that life Esperance is higher among woman population than into men population.

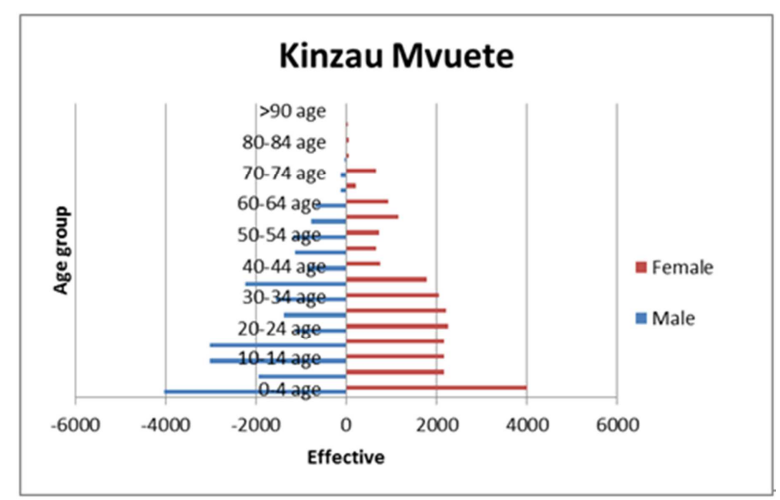

Figure 3. Age pyramid of the population of Kinzau Mvuete.
The most educated person within Kinzau Mvuete left bank quarters studied Kasa Vubu, Mobutu et Kaka di Makwala) is a Philosophical Doctor. The usual seen education level is high school. Children begin their study at the age of seven and end the high school relatively at the age of twenty. Women scholar within the entire population remain very poor and are still marginalize compare to Men. The weaknesses of the access to education is principally due to the failure of an educational state strategy and support in one hand and in other hand from premature pregnancy and hasty marriage concerning young girls; and the lack of financial means corning young men.

With a relative Men-Women proportion evidently equal (49\% versus $51 \%$ ) Kikalu and Kiyangala are respectively composed of 35 and 51 habitants for 7 and 6 families (Figure 4 and figure 5). The average family population is determined by 5 at Kikalu against 8 at Kiyangala. Each family is directed by a woman. Previously constituted of about 30 families, the absence of a population rate comprised in an interval 25-45 years old at Kikalu, are explained by a massive population migration provoked by regular land conflict.

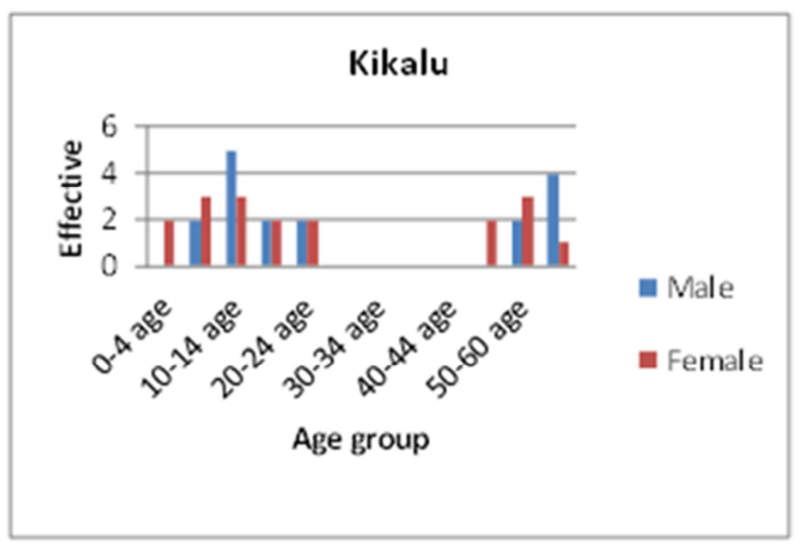

Figure 4. Distribution of the population of Kikalu villages by sex and age group.

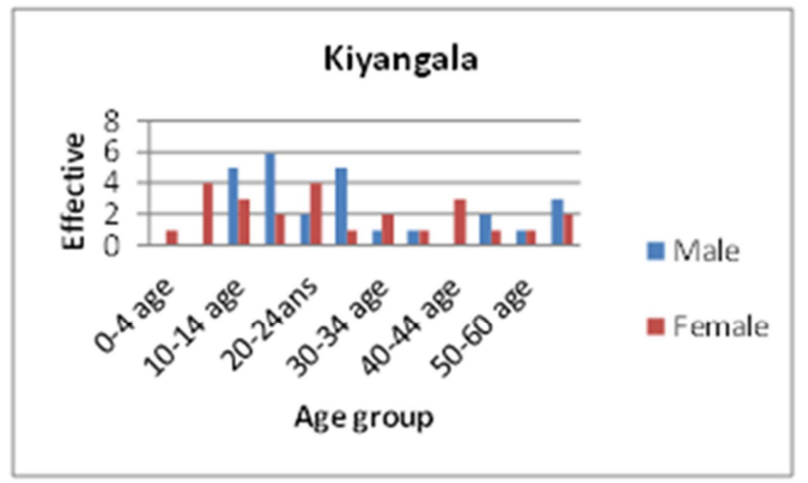

Figure 5. Distribution of the population of Kiyangala villages by sex and age group.

Figure 6 shows the distribution of the population of Kiyalala by sex and age group. This village is constituted of $39 \%$ of women and $61 \%$ of men with a family average of six persons, for an entire population of 85 habitants divided into 14 families, with four houses at his head a women; one of 
them is called "Mfumu".

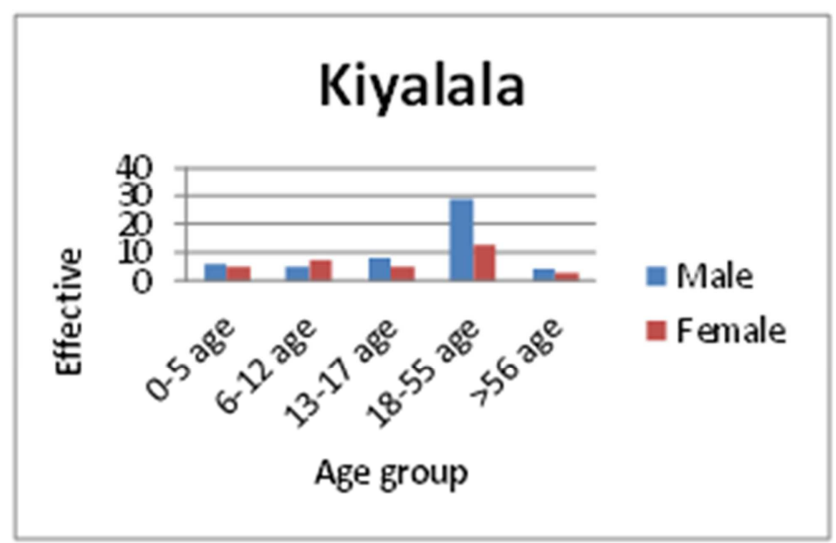

Figure 6. Distribution of the population of Kiyalala villages by sex and age group.

The lack of social base services (hospital, school, etc.), employment and entertainment infrastructures push out population from those villages toward Kinzu Mvuete city. The educational primary level is more extended in Kikalu, apart the fact that the highest level education in that zone is bachelor and the entrance in primary school age is seven years old. For the same matter students end their secondary school relatively at the age of twenty.

Some factors are responsible for that poor education records, the main are: the long distance within school and house, the lack of financial means, the insufficiency and bad quality of schools infrastructures.

In contrary to other village, Kiyalala is made up of an important adult population. The amount of population less than 17 years old represent $57.64 \%$. This situation is due to the fact that mature young person are not married because of financial difficulties. This categorical population immigrates from their village for numerous reasons: lack of employment and hard practices of agriculture. Kinzau town remains the main destination following by Cabinda and Soyo cities. The most instructed person is bachelor level; the average level study is primary. As others villages, high distance between schools and villages (4 kilometers from Kinzau) remain the major limited factor to children primary entrance (7 years old).

In global terms, lack of employment and agricultural land in the villages around, made the town of Kinzau Mvuete due to his strategically position the main center of regular traffic migration.

\subsection{Natural Capital}

The presentation and the description of land tenure system, land use and land cover constitute the elements of analysis of natural capital. This section described the place and the importance of primary sector for local populations in the area. Primary sector related to those activities which depend of ground such as agriculture, forest and hunting.

The studied shown that globally local population are small farmers. The agricultural area exploited by families is within
0.5 to one ha.. Generally estimated to 104896.3 ha, the spaces rate occupied by those products are specified in the Figure 7.

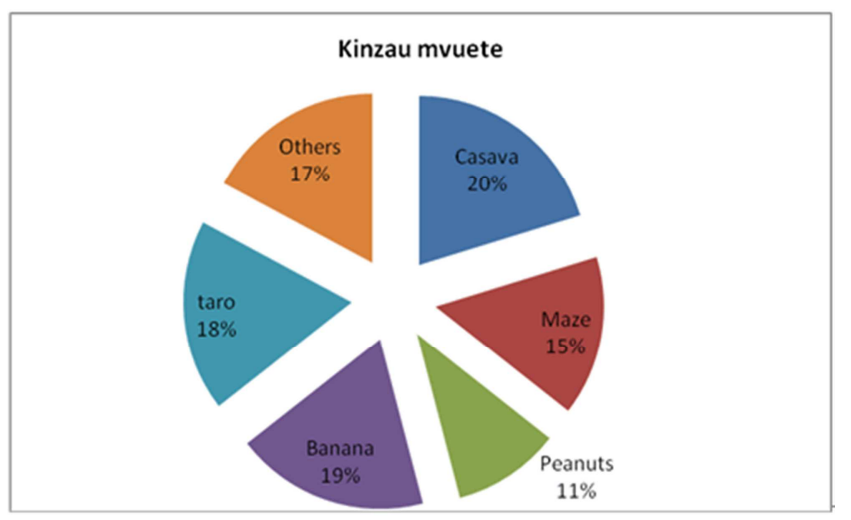

Figure 7. Percentage of basic crops grown in Kinzau Mvuete.

Cassava remains the main product and occupied $20 \%$ of the land space, followed by banana plantain (19\%), coco yam and maize. The others products representing $17 \%$ of the cultivated spaces are soya beans, groundnuts, yam, banana, potato and tomatoes.

In Kinzua Mvuete city, cultivators acquire land space cultivation throughout INERA Ngimbi land owner (for an indeterminate time for about 100 dollars US per hectare) and throughout RBL bloc-5 brigade. With land owner, the contract depends of the annual product duration. This situation is consubstantially determined by a demographical pressure constitutive to a progressive demand in terms of land, negotiated for about 10 to 100 USD per hectare. Those agricultural fields are about 5 to 28 kilometers from the city, and the trip is general walk by foot.

In the previous mentioned tree villages, peasants are lands owners, through the parental heritage. Their agricultural fields (figure 8) are located within a radius of 50 meters to 10 kilometers. Therefore, two private concessions of 60 ha at Kikalu and 10 ha at Kiyalala, inherited for a while remain. At this current time none of the private concessions are conceded in conformity to traditional rules disposals.

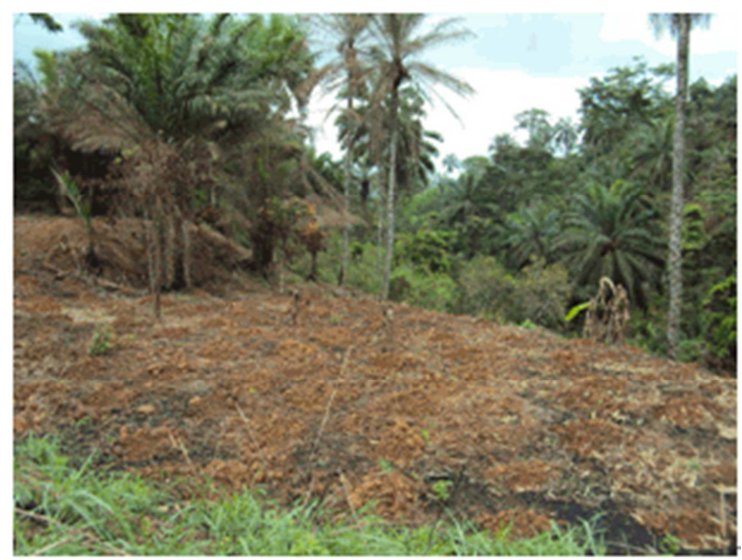

Figure 8. Agricultural clearings in block 10 of the LBR. P. Jean Semeki.

The forest is exploited for hunting activities (figure 9) 
firewood and charcoal activities. Those activities currently exist even in RLB period. About hunting activities, a hunter affirmed that « animals are become few and far (...), In two hunting days for a distance of more than $80 \mathrm{~km}$ you can only find a single zool». General poverty, lack of control, insufficiency of mean and agents of control, contribute to the pressurizing on Luki forest resources.

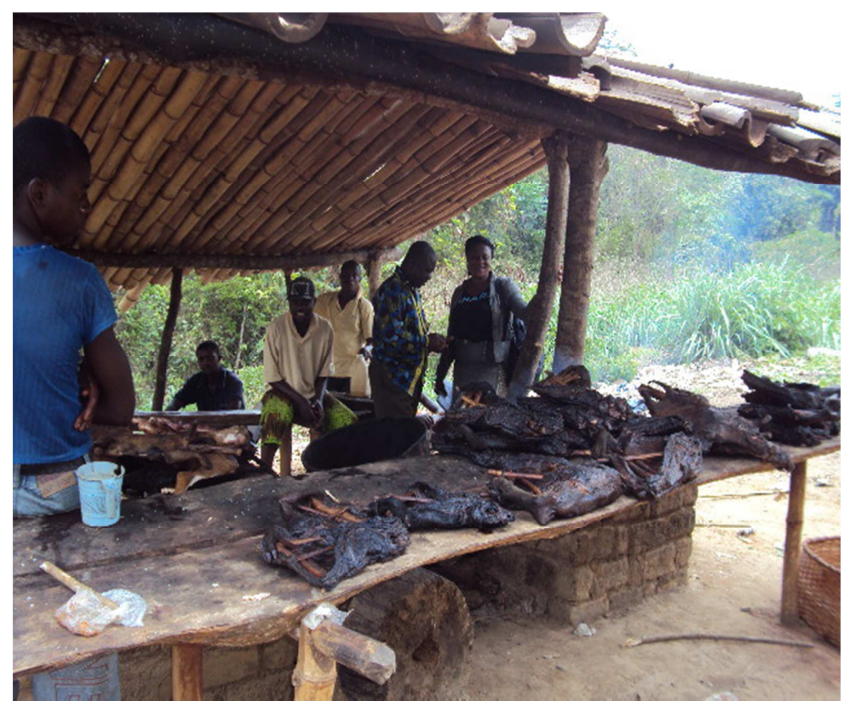

Figure 9. Sale of bushmeat in the LBR on the national one. P.Yves Meyanga.

\subsection{Physical Capital}

According to this study, physical capital related to the presentation and description of socio economy and housing infrastructures among the study area.

In Kinzau city even in Kiyalala, Kikalu, or Kiyangala villages, many roof homes are in sheet material and often fall into disrepair. Contrary in the villages houses are made of adobes brick, the city are constituted of three types of houses, clay brick, adobe brick and cinderblock brick.It also represents public services and private construction, in occurrence, the high social class. The middle social class generally adopted clay brick material for it resistance; therefore, the main population are living in houses made-up of adobe brick material. At the city size and even in the villages, toilets are essentially provided with roof material, palm leafs or adobe brick material, which is problematic in terms of wholesomeness.

Access to health bases services is problematic. None of the villages is provided by health center services, the population is obliged to reach into Kinzau city for medical services accommodations after have walking for a long distance of four to seven kilometers. Kinzau city is constituted with nine (09) private health centers, six (06) confessional health structures and four (04) public health centers, supervised by a medical doctor. All medical treatments are proposed. According to the health center, the frequent diseases encountered are malaria, gastro-enteritis, HIV/AIDS, tuberculosis, respiratory infection sickness. The major population did not have access to health services because of the default of financial mean.
Children usually go to Kinzau School and many are oblige to pass through the first national road which is very dangerous and present many risks of accidents. Kinzau educational supply is made-up of 13 schools, 8 primaries schools and 5 secondary schools. However, in the city of Kinzau we have found three nurses schools, nineteen primary schools and sixteen secondary schools, in occurrence, technical schools (mechanic and electricity), social center, a High Rural Development Institute (HRDI). This institute has trained since 19 years several teachers and technicians in the field of rural development.

Potable water represents the crucial problem in Kinzau city. Two water towers of $12.5 \mathrm{~m}^{3}$ are provided by six types of sources, each of those water towers is managed by ASBL, water providing commission, with a half-liter of water disposal per day and per person. ASBL has 68 clients which are paying their water consumption at a fixed amount of 5 USD. The insufficiency water supply is make up by five sources (in demoted state) and for about twenty undrinkable wells water (figure 10).

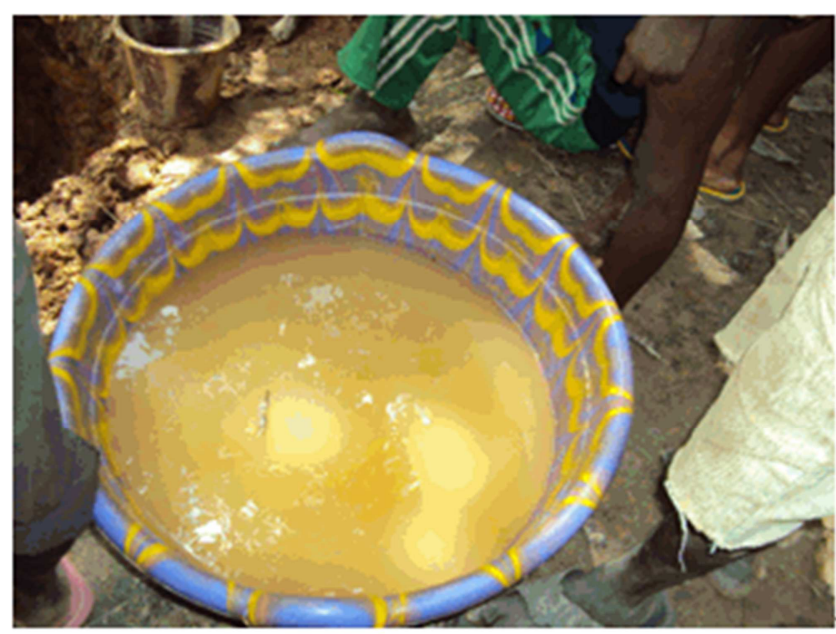

Figure 10. Well water quality used for dishwashing Kinzau Mvuete. P. Jean Semeki.

Kiyalala, Kiyangala and Kikalu villages water supply where population used to carry water are now in a worst situation, the rate of flow is wake and basely depending of annual precipitations.

Access to electricity (only existing in the city) is difficult because the SNEL clients have to provide their own electricity infrastructure. Nevertheless, the main population in the city is connected to the central network electricity, and are always confronted to an electricity decongestion.

Kiyalala, Kiyangala, Kikalu and Kinzau Mvuete are located at the first highway. The city is related to the villages through tree major roads: Kinzau-Sekebanza, KinzauKimbuani and Kinzau-Mazibidi. Those roads are seriously degraded that bring up some difficulties to dissert agricultural provision. About communicative infrastructures, two major radio station operating in Kinzau city: Kinzau Mvuete Communautary radio (RCK) and Formoza Communautary radio television (RTCF) that are broadcasting in short waves. 
At end, the telecommunication network, such as, Airtel, Vodacom, CCT and Tigo are operating in the city.

\subsection{Financial Capital}

Financial capital means to consider and to describe different sources of income and financial impact of those activities in household.

The main financial income activities are constituted of slash and burn shifting cultivation, carbonization, operating timber and hunt. Daily average financial consumption in poor house of 8 is 7, 6 USD, that mean less than 1 USD per person and per day. Concerning the middle class peasant, the annual average income is $2143,69 \mathrm{USD} /$ ha for cassava, 494, 56 USD/ha for maize and 593, 47 for groundnuts. The hunter has a daily income of 3500 FCFA. The forest exploiter, for an initial investment of 1000 USD, made a profit of $20 \%$. About carbonization, the net income is 50 USD per millstone. Apart those traditional activities, population have developed others financial income, such as carpentering, drogs sell, palm oil trade and fish sell. Those last activities are mainly controlled by immigrants coming from Kinshasa and neighborhood villages.

Above those activities, some people developed apiculture activity (figure 11), fish farming activity and modern farm, with PAPASA project, WWF within 2008-2011. A beekeeper average income is about 1099, 56 USD per year, and the fish farmer income is 543,47 to 760,86 per year.

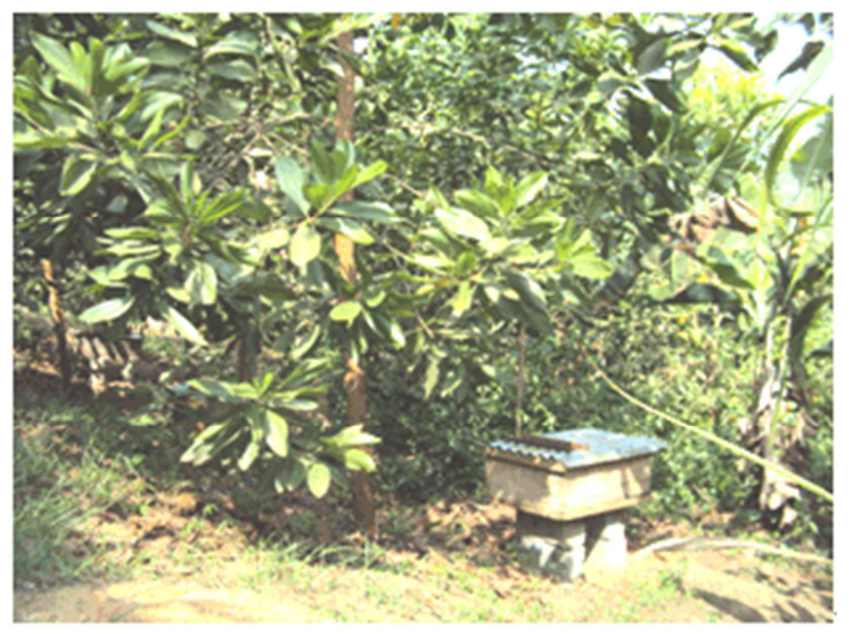

Figure 11. Bee hive for honey production in Kikalu. P. Jean Semeki.

\subsection{Social Capital}

Social capital means to describe and analyze the implication of civil society and the place of women and youth in society and to development process in the area.

Kinzau city is composed of 80 associations and local NGOs; a half of them is inactive. Their sectorial intervention activities are diversified (water, education, health, agriculture, and environment). Value system is based on popular perception on external welfare, and church role in the society. Having a home constructed with a sheet metal, been able to send children to school, have access to medical care, having a television, assuring and diversifying daily food, having a telephone, are the main determinants for life style.

The women role in a singular matriarchal society, is very prominent. Despite the fact that men remain the head of the family, women are the pillar of the house due to their implication in the education of children and house management. Agriculture is the main income generating activity and women are implicated among all the production stage whereas the contribution of men is more visible in farm cleaning and soil preparation. According to the place of the church in the society, the religious leaders are the defender of a spiritual and moral education. In that perspective, a social leader will assert that: "People instead of going to work spend their whole time by talking »

Meanwhile, unanimously, the investigations are in accordance about a serious forest disgracing. Local population estimate that forest resources management and control belong to them, otherwise state and others agents are consider as partners. This statement clearly indicating the need and aspiration of the population to a participatory forest management resources.

\section{Discussion}

The results of this research showed the RBL local population dependence to forest resources. For the general population, forest represents their natural source of life which provides them possibility in term of resources supply [1] [19]. Local villages' populations and other coming from Kinshasa, Boma, Matadi, migrate toward Kinzau Mvuete city for better pasture. Before that situation, villagers have developed livelihoods strategies such as, intensification and diversification of activities. Local cultures are practiced on the small land spaces, in disrespect of the fallow period (until 3 years). This matter is profitable to the land owners in term of consistent land financial income, which is behind land conflict $[1,9]$. The development of burn shifting agriculture contributes to the quest of a better pasture, as distant as possible. Apart those activities, carbonization, operating timber and hunt, are practiced until RBL zone. These large varieties of activities and landscape diversity seriously modify the structure and the constitution of natural environment, which consequently lead to deforestation and degradation $[1,11,14]$. This author revealed that on 45 years the Mayombe region has been transformed into secondary forest. The stabilization of the anthropic pressures throughout the emergency of REDD + will be an alternative to stop biosphere erosion in the region.

In other hand, this study has shown the limit of natural resources governance. Forest and land law system in DRC are controlled by the state. The Congo 18 February 2006 constitution stipulate that: "The state of Congo exercised a permanent sovereignty in the ground, underground, waters and forests, on the air, and also sea area and continental land » [7] [13]. The sovereignty is manifested throughout different sectorial laws. For example, forestry code, in article 7 disposed that: "forests constitute state property». In that perspective, land 
law is clear on the fact that land remains the propriety of the State: «Soil is the exclusive property of the state» [13]. The traditional law is recognized to local community on their land $[14,19]$. Practically, a certain multidimensional power in government control is concretely manifested. The land lords estimated been the singular owner of the lands and theirs resources (forest, etc.) and this right is legitimated by local population which consensually manage land business within their community. This duality generates conflict on land right within population and land owners on one hand, and within State and land owners $[3,4]$. This view is shared by Desclee [1] and Vermeulen [20]. According to Lessourd, rural spaces are defined more than in the past, in term of stakes, power relation and conflicts [8, 10, 19]. The interest is on water resources, land, tree, market control and transactions. Law implementation in that situation is difficult. The public administration is financially weak, State institutions, NGOs are then a predatory structures, determined by financial motivation in their action. Politics is widely implicated into resources management, and ministerial decisions are always against the reality on the field. For instance the decision taken in 2007 by the Ministry of environment to suspend all forestry activities in Kongo-Central province has not been follow up by compensate measure and therefore has favor illegal exploitation around the RBL.

\section{Conclusion}

The systemic analysis of different means of surviving in Luki Biosphere reserve revealed that the protected area is seriously confronted to unemployment and to a heavy exploitation of natural resources. Due to this high pressure in the forest resources, the population of Kinzau Mvuete city and of the surrounding villages of Kiyalala, Kikalu and Kiyangala have developed strategical activities and have mobilized different means to ensure their livelihoods conditions, in a context of lack of support and failure of institution and organization in forest sector and sustainable development issue. Further, the elaboration and the implementation of REDD+ process in DRC globally and particularly in Mayombe region, is confronted to the problematic of integrated systemic approach theory and analysis in the sustainable forest management process. Those strategies are entirely depended to the Luki Biosphere Reserve natural resources. Some primordial actions need to be promoted in the study areas, such as rehabilitation of agro-enterprises; reforming forestry land law, reinforce State services capabilities and local structures services; promoting agroforestry development and environmental education. Those activities have to be implemented through a participative and integrated approaches.

\section{Acknowledgements}

This study has been carried out during an extension course (STADI) held by the Regional Post-graduate Training School on Integrated Management of Tropical Forests and Lands (ERAIFT), University of Kinshasa. Each enquired village local populations are also thanking for their active participation and their franc collaboration.

\section{References}

[1] Desclee, D., Michel, B. et Trefon, T. (2018). Enquête et étude de diagnostic des capitaux et stratégies d'existence des ménages dépendants des ressources de la Réserve de Biosphère de Luki en République Démocratique du Congo. Tropicultura. 36, 3: 492-505.

[2] FAO (2015). Evaluation des ressources forestières mondiales. Comment les forêts de la planète changent-elles? Rome, Italie.

[3] Fonds National REDD+ de la RDC (FONAREDD) (2017). Modèle de document de programme REDD+. Kinshasa, RD Congo.

[4] Fonds REDD+ de la RDC (FONAREDD) (2015). Plan d'investissement REDD+ (2015-2020). Kinshasa, RD Congo.

[5] Gillet, P., Vermeulen, C., Feintrenie, L., Dessard, H., et Garcia, C. (2016). Quelles sont les causes de la déforestation dans le bassin du Congo ? Synthèse bibliographique et études de cas. Biotechnologie, Agronomie, Société et Environnement. 20, 2: 183-194.

[6] Institut national de la statistique (INS). (2015). Profil de la Province du Kongo Central. Direction provinciale, Matadi, RD Congo.

[7] Journal Officiel de la République Démocratique du Congo (JO). (2011). Constitution de la République Démocratique du Congo, numéro spécial 3, 52ème année. Présidence de la République, Kinshasa, RDC.

[8] Kakelengwa, B., Benneker, C., Matata, P. et Muganguzi, I. (2016). La foresterie communautaire face aux dynamiques locales de la gestion des forêts à l'Est de la RD Congo. Tropenbos International RD Congo, Wagenigen, Pays-Bas.

[9] Kipalu, P., Lassana, K., Bouchra, S., Vig, S. et Loyombo, W.. (2016). Sécuriser les droits des peuples forestiers et combattre la déforestation en République démocratique du Congo: Moteurs de la déforestation, impacts locaux et solutions basée sur les droits. Forest Peoples Programme (FPP), Royaume-Uni.

[10] Maindo, A., et Kapa, F. (2014). La foresterie communautaire en RDC: premières expériences, défis et opportunités. Tropenbos International RD Congo.

[11] Molinario, G., Hansen, M. C., Potapov, P. V. (2015). Forest cover dynamics of shifting cultivation in the Democratic Republic of Congo: a remote sensing-based assessment for 2000-2010. Environmental Research Letters, 10 (9).

[12] Molinario, G., Hansen, M. and Potapov, P. V. (2017). Forest cover dynamics of shifting cultivation in the Democratic Republic of the Congo 2000-2010. Environmental Researche Letters, 12 (089501).

[13] Mpoyi, A. M. (2013). Amélioration de la gouvernance du secteur foncier en République Démocratique du Congo. CODELT, Kinshsa, RD Congo.

[14] Nyange, N. M. (2014). Participation des communautés locales et gestion durable des forêts: Cas de la Réserve de Biosphère de Luki en RDC, Thèse de doctorat, Université de Laval et Université de Kinshasa. 
[15] Nissen, C. (2015). Mise à jour de la base des données cartographiques par télédétection spatiale de l'occupation et de l'utilisation du sol dans la région de Luki en RDC, Mémoire de fin d'étude pour l'obtention du diplôme de bioingéniur en gestion des forêts et des espaces naturelles, Université Catholique de Louvain, Belgique.

[16] Saint-Amand, A. (2014). Simulation numérique des changements de couvert forestier dans la région de la Réserve de Biosphère de Luki (RDC), de 2000 à 2012, Mémoire de fin d'étude pour l'obtention du diplôme de bioingénieur, Université Catholique de Louvain, Belgique.

[17] Tchatchou, B, Sonwa, D. J, Ifo, S., et Tiani, A. M. (2015). Déforestation et dégradation des forêts dans le Bassin du Congo: État des lieux, causes actuelles et perspectives. CIFOR, Bogor, Indonésie.

[18] Valery, G., Dubiez, E., Boulogne, M., Gigaud, M., Péroches,
A., Pennec, A., Fauvet, N., et Peltier, R. (2016). Forest cover and carbon stock change dynamics in the Democratic Republic of Congo: Case of the wood-fuel supply basin of Kinshasa. Bois et forêts des tropiques, 327,1:19-27.

[19] Van Vliet, N., Vanegas, L., Sandrin, F., Cornelis, D., Le Bel, S., Dominique, E., Gevais, O. O., Gaidet, N., Fargeot, C., Essiane, E., Sicard, J. -C., Gely, M., Lescuyer, G., Billand, A., Nasi, R., Jepang, C., Ayaya, I,. Broussolle, L., Muhindo, J., Houngbegnon, F., Fagot, R., Mve Ba Zibe, S.A., Granier, E., Kidiba, A, Yapi, F. et Ngohouani, D. (2017). Diagnostic approfondi pour la mise en œuvre de la gestion communautaire de la chasse villageoise: Guide pratique et exemples d'application en Afrique centrale. Guide. CIFOR, Bogor, Indonésie.

[20] Vermeulen, C. (2014). Enjeux autour des forêts congolaises. Cahiers africains. 84:223-235. 